\title{
POSSIBILITIES OF RESOLVING THE DILEMMA 'POWER-KNOWLEDGE' IN THE PROCESS OF THE CIVIL SOCIETY FORMATION IN UKRAINE
}

\begin{abstract}
This article deals with the possible search for a solution to the "power-knowledge" dilemma in the context of the formation of a civil society in Ukraine. The articles examines the causes and the need for carrying out constructive reforms in education, in order to overcome the alienated nature of the power-to-education relationship. The problem is viewed alongside current research on reforming national education, including by contemporary theorists of educational philosophy such as Jose Ortego-i-Gasset, Marek Queck, Andy Greene, Karl Popper, and Paulo Freire. We argue that it is the critical consciousness in the field of pedagogical activity that shapes the creative approach to modern education and science. In the Ukraine, it is possible to obtain positive results in educational reform through the democratization of educational activity. Only through overcoming the contradiction of "power-knowledge" - and other forms of alienation of education from power can one gain a positive constructive in the field of educational activity.
\end{abstract}

Keywords: dilemma, power, knowledge, civil society, educational reforms, philosophy of education, democracy of education, globalization, nation-state, educational institutions, regulatory idea of education, rationality, spiritual culture, subject-subject relations, new paradigm of education, critical consciousness, practice of freedom.

\section{INTRODUCTION}

An important feature of nowadays is the extraordinary transience of radical changes taking place in society, many of which are radical in nature. In a short historical time, the political face of many countries around the world, and in particular, Ukrainian society, has changed significantly.

In the reality of sovereign Ukraine, a new person has grown and formed, or rather a person with a "national-patriotic character". Proof of this are modern socio-political events related to the European choice of Ukrainians and the practical implementation of the government's program of action to bring Ukrainian society closer to the civilized spiritual and cultural world values.

\footnotetext{
${ }^{1}$ Serhii Sheiko, PhD, Professor at the Department Of Humanities And Social Sciences Of Poltava State Agrarian Academy; e-mail: Sergii.Sheiko@pdaa.edu.ua (corresponding author). ORCID: 0000-0002-4635-4643.

2 Olena Kolodii, PhD, Associate Professor at the Department of Humanities and Social Sciences of Poltava State Agrarian Academy; e-mail: rotcat@ukr.net. ORCID: 0000-0002-4314-8676.
} 
This process clearly demonstrates the new level of development of national consciousness of citizens and the formation of a qualitatively new democratic character of the Ukrainian people, which emerged and formed during the years of independence of our state, as one of the necessary foundations for civil society in Ukraine.

The purpose of the article is to clarify the possibility of overcoming the alienation in relation to "power-education" under the condition of constructive reforms in the educational field.

In the historical context, reforms in society and education are constantly ongoing. They take place in different socio-cultural epochs, inherent in almost every century or even decades now, and differ depending on the acceptance of the overall goal, idea, construct of national education and its practical implementation.

The processes of educational reforming cannot be temporary, accidental, isolated, and even worse, imitation or falsification of the necessary objective changes. The reasons for reforming educational and scientific activities relate not only to improving the content of education, the introduction of new pedagogical technologies and appropriate psychological support, but above all, a radical change in the whole set of social relations of the relevant type of socio-political reality.

\section{PROBLEM DISCUSSION}

Reform is always the creation of a new order. Thus, according to the Spanish philosopher-educator of the XX century Jose Ortego-i-Gasset, the need for educational reform arises for two main reasons: "either because of violations in the literal sense of the word, i.e. because of isolated cases of misapplication of good rules", or because that "abuses happen so often or constantly, they become so common or even approved that they can no longer even be called abuses" (Jose Ortego-i-Gasset, 2002).

Therefore, qualitative radical changes need to be directed against the latest violations. However, the process of reforming education should have sufficient basis, find practical implementation and general approval in the case of objective and true definition of the common mission, the idea of educational institution and solving the problem of national and civil relations, contradictions "power-knowledge" in the democratic society in Ukraine.

For modern Ukrainian education it is important to find its own answer to the questions constantly asked by modern philosophers-educators: how to preserve the historical national tradition, not to lose past positive achievements and at the same time direct all creative energy to the development of future education, or, in the other words, democratic basis of education and full entry into the Western European educational space? Solving this problem is the most important task in the process of radical reform of higher education in Ukraine.

In the current era of globalization, education is undergoing a qualitative transformation, with a weakening of the role of the nation state in this process. According to Marek Queck, a modern Polish sociologist of education, the most pressing antagonisms of late modernism were "international integration" or "national disintegration", "globalization" or "internal social stability". The question of reducing the role of the nation state resonates with the question of the "socio-humanitarian consequences of globalization", the end of modernism, the "end of history", the "death of the intellectual" and the disappearance of national educational institutions (Kwiek, 2002).

The completion of the socio-cultural, political project of modernity affects both sides of the "power-knowledge" relationship, because both knowledge and power of the modern 
nation-state change their configuration. The formation of national education in Western Europe coincides in time with a significant revival of national movements, the growing importance of the nation-state, promoting the formation of nationally conscious individuals - citizens of sovereign nation-states.

On this basis, there is a well-known alliance between modern scientific knowledge, education and modern government, which is embodied in educational institutions, especially the national universities of the late Middle Ages and the Western European Renaissance. In the current conditions of globalization of the late XX-early XXI centuries, the role of the nation state as a socio-political and cultural-educational project is significantly weakened; there is a real tectonic shift in relations between "government and education".

The regulatory idea of the Enlightenment was rationality, logic, and later in the philosophical and educational treatises of Friedrich Schleiermacher and Wilhelm von Humboldt it became spiritual culture, education that is constantly self-cultivated in the person of the subject of the nation-state. After two centuries of domination in the culture field, the traditional social mission of the educational institution as a continuation of the development of the nation-state suddenly lost its previous constructive significance and became the subject of sharp scientific and public discussions.

An important cultural and educational project of the modern era is step by step pushing out its own potential. The question arises again: what should the regulatory idea of educational activity focus on? Again, scientists and pedagogical communities stopped in search of a modern principle, a regulatory idea of the existence of postmodern education.

Prominent English philosopher of the twentieth century Karl Popper, author of the world-famous work "Open Society and its enemies" noted that "the mind, like science, develops through mutual criticism". Its development is aimed at improving the institutions that "stand guard over free criticism, i.e. free thought" (Popper, 1994).

By adapting the principles of critical consciousness to teaching, Karl Popper argues that the teacher should not impose his measure of "higher" values on students, but should try to arouse their interest in those values. He must take care of the souls of his students. (Popper, 1994). The foundations of a critical worldview as a sufficient basis certainly contribute to the formation of an open civil society and the preliminary solution of the controversial dilemma of the relationship "power-education".

Critical thinking forms, first of all, a creative approach to any practical human activity. Creative creativity encourages the democratic foundations of human communication. Therefore, the teacher, to whom the community has entrusted the formation of active purposeful individuals, must take into account the principles of cooperation, dialogue, tolerance. "We must not harm in the first place" - this should be recognized as the main educational activity.

Do no harm, and therefore, "give young people what they feel an urgent need to become independent of us and able to make their choices - this would be a very useful goal for our educational system" (Popper, 1994). Thus, the formation of critical consciousness in the education system directs the activities of mentors to the education of creativity, full dialogue, understanding and constructive cooperation.

On the way to democratization of all levels of educational activity in Ukraine, including radical, qualitative changes in socio-political life, development of a scientifically sound goal of educational work, it is possible to achieve the desired positive results of the process of 
education reform. Only by overcoming the contradiction "power-knowledge" and various forms of alienation of power from education can we get the appropriate paradigm.

According to the Brazilian philosopher-educator of the twentieth century Paulo Freire, critical consciousness is formed in the process of formation of the subjectivity of the individual within the development of socio-historical practice and the process of human life. Men and women as subjects in the process of cognition (and not the recipients of "knowledge" that others give or impose on them) move to the essence of reality. Reality step by step, more and more shows them the world of demands and opportunities, determinism and freedom, denial and assertion of their humanity, permanence and transformation, values and devaluation, expectations in the hope of search and expectations without hope of fatal inaction (Freire, 2003).

Paulo Freire's education method is a practice of freedom, because it frees the teacher, no less than his students, from the double slavery of contemplative silence and monologue. Both partners self-liberate when they begin to learn: one - to know himself as a worthy person, and the other - to achieve the ability to creative dialogue.

At the turn of the millennium, political scientist Andy Greene argues that in the "postnational era" national education system becomes "dead, anachronistic, inappropriate, suddenly loses its meaning" (Kwiek, 2002). Modern problems of education go much deeper, affecting the problems of the public sector of society. Today, the revision of the "power-knowledge" relationship takes place in two spheres: in terms of the functioning of a modern independent nation-state and a modern welfare state within the framework of civil society development.

In the case of higher education, the general direction of the reforms identified by the governments of the globalized world with the overwhelming support of supranational organizations in the context of the spread of libertarianism is aimed at introducing lifelong learning for all, the widest possible access to knowledge for a reasonable fee, intensive training in institutions that are financially independent and constantly market-oriented. This trend of development today is obvious everywhere and corresponds to the relationship "power-knowledge", i.e. the relationship between the modern nation-state and the modern University (Kwiek, 2002). Harmony between the nation-state and previous educational institutions lasted as long as modern "forms of power and knowledge" were in balance.

The ruthless logic of consumerism, pragmatism, bureaucracy, formalism, and selfishness, which gave rise to the idea of "brilliant education" in the shortest possible time, bordering on the constant facts of corruption and bribery in educational institutions, has become a terrible phenomenon in the process of alienating power from education in modern conditions. The purpose of such "education": to supply an attractive product at a reasonable price, to provide society with "good goods" for his money. Thus, in such conditions, national self-consciousness will no longer play a major role in the social life of information-developed countries, and national identity will not be the main dominant factor for the society of the late modern era.

The spiritual and cultural life of the citizens of a rational nation-state becomes unconditionally subject to the principles of subjective pragmatism, consumption, selfishness and constant manifestations of formalism and bureaucracy in various spheres of educational and scientific activity. In the current conditions of the predominance of postmodern values, the universalism of rationality and spiritual culture lose their relevance, being replaced by "postmodern sociology of pluralization, relativization, deconstruction of 
the modern knowledge system, devalued by the erosion of postmodern science" (Tancher, 2006).

The search for a new paradigm of future education and its practical institutions is undoubtedly linked to the ideals of building civil society, but how to make a difficult transition from national to civic ideals in the current socio-political situation? Polish researcher Marek Queck states that "the future silhouette of the University was in the process of formation. It is extremely interesting to watch him, it is more useful, however, to understand him, and the most useful thing is to try to influence him" (Kwiek, 2002). This should be the constructivism of modern pedagogical action and its ideological and methodological understanding and practical implementation of the conceptual foundations of the philosophy of education.

It is a well-known fact that any knowledge has a pronounced socio-practical character, and knowledge about society is special, because social relations are studied by the subjects of these relations. Socio-humanitarian knowledge always depends on the conditions created for scientists and the interest of the authorities. Sociology, first of all, reflects the qualitative characteristics of the development of national societies. An important task for the socio-humanitarian sciences is not only the description and generalization of the facts of social life, the disclosure of significant development trends, but first of all, the explanation of the meanings of various social phenomena, the definition of values and forecasting the basic meanings of social life and the construction of the social world.

According to the Ukrainian sociologist Viktor Tancher, these two approaches to the tasks of sociological knowledge can be conditionally called "pragmatic-positivist" and "activist-humanizing", which will become indispensable attributes of sociological activity (Tancher, 2006).

Authoritarian regimes are more sympathetic to the service functions of sociology, and democratic - to the critical-cognitive, human-humanizing, perspective-predictive analytical developments in the fields of socio-humanitarian knowledge. A striking example of the contradictory relationship between sociology and power are the turbulent events in the American sociological community in the late 60's - early 70's of the twentieth century. A number of scholars, representatives of socio-humanitarian knowledge, such as A. Gouldner, I. Horowitz, G. Marcuse, M. Zeitlin, D. Rong began to criticize the official pro-government sociology, because "academic sociology" is subordinate to the ruling class, it collects only "useful" for pro-government institutions information, while the task of sociological criticism is in the opposite direction, in the interests of all civil society, "who are exploited and oppressed".

The main content of the supporters of critical sociology, or "sociology of sociology" is to expose the conservative nature of the vast majority of sociological developments and the inability of social analysts to serve the interests of the general population, accusations of servitude. The main question in the field of critical sociology arose as follows: how to cooperate "professional sociology" with the government and, at the same time, to maintain certain autonomy, independence from it. Critical analysis of the relationship between social science and government has revealed the obvious dependence of social researchers on the power structures of society, state institutions and dispelled the positivist myth of objectivity, impartiality and impartiality of sociologists working for pro-government institutions. The problem of the relationship between "social science and practical policy" has retained the same meaning today. 
In modern times, in which the socio-political system was based on rational preconditions, knowledge was an important resource, a means of social control. The current postmodern situation puts before the sociology of the XXI century the general goal of disseminating social information, which is designed to democratize social institutions to the general public.

The urgent task of modern sociological science is to create a new "practical sociology" that is designed to serve the formation and development of civil society, rather than be "academically excluded" from the needs of protecting the rights and freedoms of citizens. In the conditions of modern globalization processes there is a withdrawal from the ideas of state-centric policy, instead, the importance of the public, socio-political movements grows, because they, not the nation-state, become the center of political activity. Harmonization and democratization of power relations and socio-humanitarian knowledge will certainly contribute to the development of the diversity of civil society institutions in Ukraine. It is civil society that will act as a mediator between government and science and will be the customer of social research. Thus, the search for the right solutions in the field of dialogue between government and knowledge is expected with the involvement of the general public.

The possibility of solving the dilemma "power-knowledge" or "power-education" is on the way to a significant scientific understanding of the overall project of building civil society in Ukraine. To this end, it is necessary to thoroughly develop critical thinking and its practical application in pedagogical activities in the direction of democracy and the formation of subject-subject dialogue based on cooperation and mutual understanding.

A developed nation is characterized not only by the level of social welfare, but by the ability of highly educated, critically thinking people to identify and solve socio-political problems in a timely manner, without creating other, even more terrible problems. "A developed nation is not a mass that is skillfully guided, God forbid, by a reasonable and decent top, but a dialectical unity of free and independent people who in dialogues determine the directions and ways of their personal and social development" (Freire, 2003).

\section{CONCLUSIONS}

The historical "call" of a nation is to become transformers of its social reality. Only in this way do individuals become subjects, not objects of their own history and existence. The position of some politicians and some government agencies on reforms for the sake of reforms in Ukrainian education and science is often detached from the urgent needs of objective pedagogical reality, the practical life of educators, filled with bureaucracy, formalism and casual pragmatism does not stand up to criticism. Therefore, the solution of the important dilemma "power-education" is possible only through close cooperation of state structures with government institutions and public organizations, which become relevant in the context of active development of civil society in Ukraine.

\section{REFERENCES}

Derrida, J. (2002). The law of sufficient grounds: University through the eyes of yoga followers [The idea of the University: Anthology, ed. by: M. Zubrytska, H. Babalik, Z. Rybchynska]. Lviv: Litopys.

Freire, P. (2003). Formation of critical consciousness [transl. from English by O. Demyanchuk]. Kyiv: Yunivers.

(2003). Pedagogy of the oppressed. Kyiv: Yunivers. 
Kwiek, M. (2002). Nation-state, globalization and the university as a modern institution [The idea of the University: Anthology, ed. by: M. Zubrytska, H. Babalik, Z. Rybchynska]. Lviv: Litopys.

Ortego-i-Gasset, J. (2002). Mission of the University [The idea of the University: Anthology, ed. by: M. Zubrytska, H. Babalik, Z. Rybchynska]. Lviv: Litopys.

Popper, K. (1994). Open society and its enemies. Kyiv, Vol. 1.

Scott, P. (2001). Higher Education Reform in Central and Eastern Europe: An Analysis Attempt. Bulletin of the Higher School. Moscow.

Sheiko, S.V. (2005). National and civic principles of reforming modern higher education in Ukraine. Higher Education of Ukraine, 3 (7). Kyiv: Institute of Higher Education of the Academy of Pedagogical Sciences of Ukraine.

Sheiko, S.V., Kolodii, O.S. (2018). Philosophical and educational foundations of the personality development of the higher school teacher in the 21st century. Management of the 21st century: globalization challenges [monograph].

Tancher, V. (2006). Social knowledge and power: contradictory interdependence [Values of civil society and moral choice: Ukrainian experience]. Kyiv: Etna-1.

DOI: $10.7862 /$ rz.2020.hss.34

The text was submitted to the editorial office: March 2020.

The text was accepted for publication: September 2020. 
